\title{
CHLOROPHYLL LOSS PERCENTAGE AS INDICATOR FOR CALCULATING ECONOMIC THRESHOLD AND ECONOMIC INJURY LEVELS OF PARLATORIA ZIZIPHI (LUCAS) ON NAVEL ORANGE LEAVES
}

\author{
H. A. Nabil \\ Plant Protection Research Institute, ARC, Dokki, Egypt \\ Received: Mar. 12 , 2019 \\ Accepted: Apr. 30, 2019
}

\begin{abstract}
This study was carried out in Scale Insects and Mealybugs Department, Plant Protection Research Institute, Sharkia Branch, ARC, Egypt from May to September 2017 on navel orange leaves infested with the Parlatoria black scale, Parlatoria ziziphi (Lucas) to calculate economic threshold and economic injury levels depending on the loss of leaves chlorophyll content. Simple correlation and partial regression were calculated between numbers of insect and chlorophyll loss percentage in infested and uninfested units (inch ${ }^{2}$ ). Positive highly significant correlation was recorded between numbers of insect and percentage of chlorophyll loss. Chi-square $\left(X^{2}\right)$ was used to calculate economic threshold and economic injury levels of $P$. ziziphi that causes economic damage in disk chlorophyll content which were 9 and 14 individuals per inch ${ }^{2}$, respectively.
\end{abstract}

Key words: Sap-sucking, hemipterans, Parlatoria black scale, chlorophyll, Simple correlation, partial regression

\section{INTRODUCTION}

Scale insects are some of the most unusual hexapod known. Their common name derives from the frequent presence of a protective covering or 'scale' or from the appearance of the insects themselves. Scale insects or coccoids (Coccoidea) are sap-sucking hemipterans insects. They are most important as agricultural pests of perennial plants and can cause serious damage to fruit trees, woody ornamentals, forest vegetation, greenhouse plants, and house plants. Main damage is usually caused by removal of plant sap, but also may be caused by plant pathogens transmission, injection of toxins and the production of large quantities of honeydew with resultant growth of sooty mold fungi that cover leaf surfaces and reduce photosynthesis. More damages are distortion of foliage, discoloration of flowers, galls and tumors formation, distorted blossoms, reduction in the general vigor of the trees, reduction in quality and salability of fruits, dieback of twigs and sometimes the death of the entire plant (Elhendawy, 2018).

Herbivore caused leaf chlorosis in growing plants should be studied in detail, as chlorophyll fluorescence might prove useful as an indicator of plant responses to stressors including insect damage (Haile et al., 1999). Chlorophyll content is one of the most important parameters in the relationships between plants and herbivores. Chlorophyll levels change during plant development (Costa et al., 2001), and can alter in response to a wide variety of stresses (Fanizza et al., 1991, Samdur et al., 2000, Lawson et al., 2001).

Leaf feeding by sap feeding insects causes chlorosis and necrosis, leading to significant crop loss worldwide. Chlorophyll catabolism is equal to global chlorophyll synthesis, and can be reduced by insect feeding, nutritional 
deficiencies and pathogen infections ( $\mathrm{Ni}$ et al., 2001 \&2002).

Few studies have been conducted to assess the effect of feeding insects on chlorophyll levels such as aphids and scale insects (Golawska et al., 2010, Nabil and El-Shafiey, 2011 and Nabil, 2013). Whoever, till now no similar studies have been conducted to assess the effect of feeding by Parlatoria black scale, Parlatoria ziziphi (Lucas) on chlorophyll levels, this research represents an initial effort to characterize the effect of $P$. ziziphi on chlorophyll a and $b$ loss in navel orange leaves.

This work aimed to determine the concentrations of photosynthetic pigment (chlorophyll $a$ and $b$ ) in infested and uninfested navel orange leaves to calculate economic threshold and economic injury levels for $P$. ziziphi on navel orange leaves. Economic threshold and economic injury level numbers were very important numbers because between those chemical control must be took place.

\section{MATERIALS AND METHODS}

Experiments were carried out at Scale Insects and Mealybugs Department, Plant Protection Research Institute, Sharkia Branch, ARC, Egypt on navel orange, Citrus sinensis (L.) to determine the loss of chlorophyll content in navel orange leaves by infestation with the Parlatoria black scale, Parlatoria ziziphi (Lucas).

The study was carried out from May to September 2017, in an area of about one feddan of navel orange. For sampling, mature leaves were picked up randomly and put in black polyethylene bags and transferred into the laboratory. The leaves were divided into disks (square inch) were examined in the same day by the aid of stereomicroscope. The adult females of $P$. ziziphi were counted and recorded (Nabil and El-Shafiey, 2011 and Nabil, 2013).
The chlorophyll content average (chlorophyll $a$ and chlorophyll $b$ ) in 25 disks $\left(\right.$ inch $^{2}$ ) of navel orange leaves for every level of infestation and uninfested disks as control were extract and determine spectrophotometrically according to (Moran, 1982) as following:

The immersion leaflet disks in $5 \mathrm{ml}$ of $\mathrm{N}, \mathrm{N}$-Dimethyl formamide at least $48 \mathrm{hrs}$. Concentration of chlorophyll $a$ and $b$ were determined spectrophotometricaly from absorbance at 647 and $664 \mathrm{~nm}$, respectively. The pigment concentrations were calculated using the following equations:-

Chlorophyll a $\left(\mathrm{mg} / \mathrm{inch}^{2}\right)=12.64 \times \mathrm{E} 664-$ $2.99 \times \mathrm{E} 647$

Chlorophyll $b\left(\mathrm{mg} / \mathrm{inch}^{2}\right)=23.26 \times \mathrm{E} 647-$ $5.6 \times \mathrm{E} 664$

Total chlorophyll (mg/ inch $\left.{ }^{2}\right)=$ Chlorophyll $\boldsymbol{a}+$ Chlorophyll $\boldsymbol{b}$

Simple correlation ( $r$ ) between number of insects per disk and percentage of chlorophyll loss was studied using COSTAT Computer Program (2005).

According to Little and Hills (1972), Salem and Zaki (1985), Hassan (1998), Nabil and El-Shafiey (2011) and Nabil (2013) the partial regression formula "Cmultipliers" independent variance (X) represent the scale insects per disk, the dependent variance $(Y)$ represent percentage of chlorophyll loss per disk. Simple correlation (r) and simple regression (b) were calculated. The slope (b) of the straight regression line was carried out to obtain the corrected values for the percentage of chlorophyll loss.

Chi-square $\left(X^{2}\right)$ was used to calculate economic threshold and economic injury levels for $P$. ziziphi that causes economically damage in disk chlorophyll content.

\section{RESULTS AND DISCUSSION}

Data presented in Table (1) and Fig. (1) revealed that percentage of chlorophyll 
content loss per unit was significantly declined with increasing of insect numbers. There was positive highly significant difference between number of insects per disk and percentage of chlorophyll loss where (r) value was $0.960^{* *}$.

Simple correlation and partial regression and chi square were used to calculate economic threshold and economic injury levels, Chi-square analysis was applied for mathematic determination of the point at which the increase of insect number caused a significant effect on chlorophyll loss percentage. Results revealed that economic threshold and economic injury levels were 9 and 14 insects per disk, respectively.

Results showed that there was positive highly significant between number of females and percentage of chlorophyll loss.

Table (1): Numbers of insect, Parlatoria ziziphi (Lucas) and percentage of chlorophyll loss on navel orange leaves per disk and chi square values

\begin{tabular}{|c|c|c|c|c|c|c|}
\hline $\begin{array}{c}\text { No. of } \\
\text { femalesl } \\
\text { inch }^{2}(X)\end{array}$ & $\begin{array}{l}\text { Chlorophyll } \\
\text { content } \\
\left(\mathrm{mg} / 2 \text { inch }^{2}\right)\end{array}$ & $\begin{array}{l}\text { Chlorophyll } \\
\text { loss }(\mathrm{mg} / \\
\left.\text { inch }^{2}\right)(\mathrm{Y})\end{array}$ & $\begin{array}{c}\text { \% loss } \\
\left(\mathrm{Y}_{\mathrm{Ob}}\right)\end{array}$ & $\begin{array}{c}\text { Calculated } \\
\left(\mathrm{Y}_{\mathrm{Ex}}\right) \%\end{array}$ & $\frac{\left(Y_{O b}-Y_{E X}\right)^{2}}{Y_{E x}}$ & $\Sigma x^{2}$ \\
\hline 1 & 43.374 & 3.775 & 8.01 & 16.37 & 4.26 & 4.26 \\
\hline 2 & 42.860 & 4.289 & 9.10 & 17.54 & 4.06 & 8.32 \\
\hline 3 & 41.241 & 5.908 & 12.53 & 18.70 & 2.04 & 10.36 \\
\hline 4 & 40.242 & 6.907 & 14.65 & 19.87 & 1.37 & 11.73 \\
\hline 5 & 38.174 & 8.975 & 19.04 & 21.03 & 0.19 & 11.92 \\
\hline 8 & 35.300 & 11.849 & 25.13 & 24.53 & 0.01 & 11.93 \\
\hline 9 & 32.336 & 14.813 & 31.42 & 25.69 & 1.28 & 13.28 \\
\hline 14 & 31.278 & 15.871 & 33.66 & 31.52 & 0.15 & 13.36 \\
\hline 16 & 27.878 & 19.271 & 40.87 & 33.85 & 1.46 & 14.82 \\
\hline 21 & 25.389 & 21.760 & 46.15 & 39.67 & 1.06 & 15.88 \\
\hline 25 & 21.521 & 25.628 & 54.36 & 44.33 & 2.27 & 18.15 \\
\hline 31 & 18.380 & 28.769 & 61.02 & 51.32 & 1.83 & 19.98 \\
\hline 39 & 14.569 & 32.580 & 69.10 & 60.64 & 1.18 & 21.16 \\
\hline 53 & 13.600 & 33.549 & 71.16 & 76.95 & 0.44 & 21.60 \\
\hline 57 & 12.265 & 34.884 & 73.99 & 81.60 & 0.71 & 22.31 \\
\hline 61 & 9.576 & 37.573 & 79.69 & 86.26 & 0.50 & 22.81 \\
\hline Control & 47.149 & & & & & \\
\hline
\end{tabular}

$r=0.960^{* *} Y=15.21+1.16 X$ 


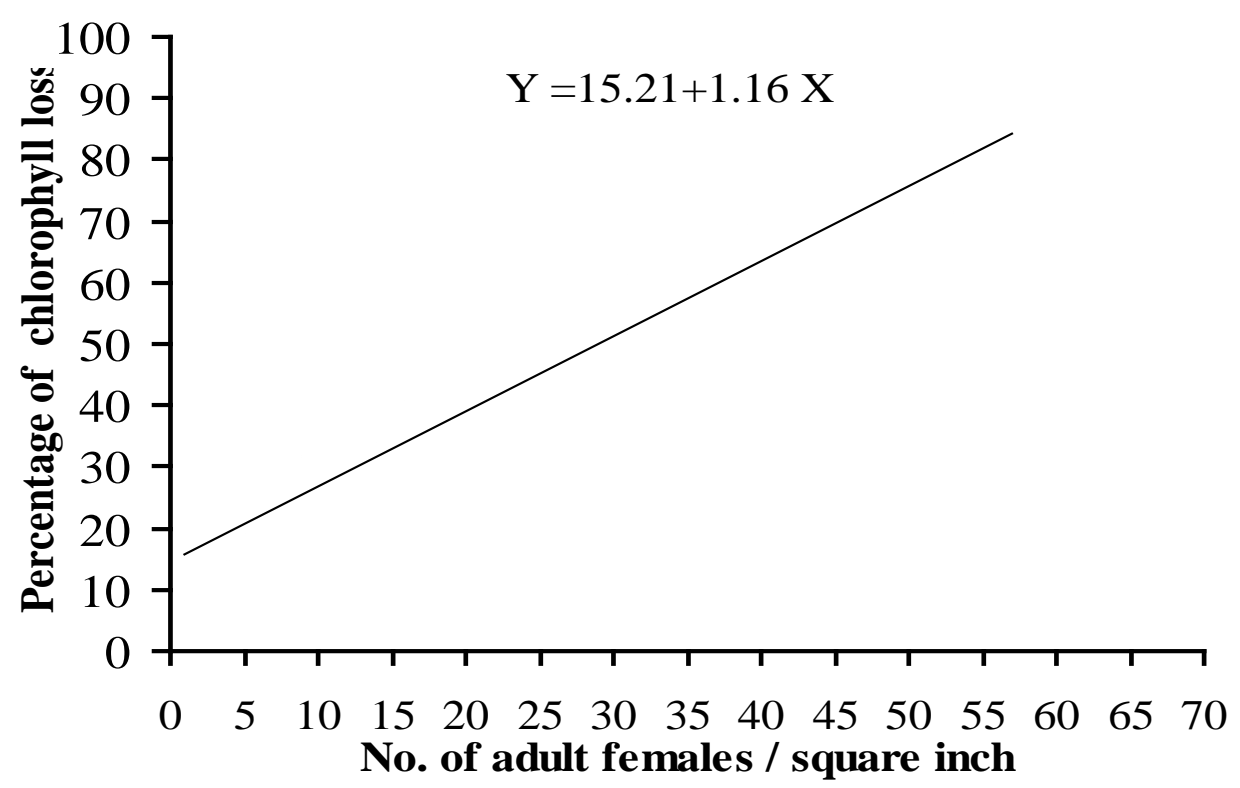

Fig. (1): Relationship between insect numbers of Parlatoria ziziphi (Lucas) per disk and percentage of chlorophyll loss.

This result was agreed with those of Golawska et al. (2010) who determined the chlorophyll $a$ and $b$ levels in uninfested leaves and in leaves after 7 and 17 days of aphid infestation in four Fabaceae species (Pisum sativum L., Vicia faba L., Trifolium pretense L, Medicago sativa L.). Feeding by pea aphids Acyrthosiphon pisum Harris (Hemiptera: Aphididae) caused significant loss of chlorophyll $a$ and $b$ in the infested plants. Uninfested leaves on both short and long infestation plants had significantly higher chlorophyll $a$ and $b$ than infested leaves. In this study the amount of chlorophyll differed between infested and uninfested navel orange leaves. The chlorophyll $a+b$ concentration in uninfested leaves was significantly higher than infested ones.

Nabil and El-Shafiey (2011) studied the reduction on chlorophyll concentration between infested and uninfested mango leaves with white mango scale insect, Aulacaspis tubercularis (Newstead), the uninfested leaves had higher levels of chlorophyll in comparison with infested ones. Economic threshold and economic injury levels were determined depended on the loss percentage of total chlorophyll on mango leaves were 3 and 5 insects per inch ${ }^{2}$, respectively.

\section{REFERENCES}

Costa, C., L.M. Dwyer, P. Dutilleul, D.W. Stewart, L.B. Ma and D.L. Smith (2001). Inter-relationships of applied nitrogen, SPAD, and yield of leafy and non-leafy maize genotypes. Journal of Plant Nutrition, 24: 1173- 1194.

Costat (2005). Version 6.311, Copyright(c), CoHort Software, 798 Lighthouse Ave. PMB 320, Monterey, CA, 93940, USA.

Elhendawy, Safaa H.A. (2018). Ecological studies on some species of scale insects infesting citrus trees at Menoufia Governorate. M.Sc. Thesis, Fac. of Agric., Menoufia Univ., Egypt.

Fanizza, G., L. Ricciardi and C. Bagnulo (1991). Leaf greenness measurements 
to evaluate water stressed genotypes in Vitis vififera. Euphytica, 55: 27-32.

Golawska, S., R. Krzyzanowski and I. Lukasik (2010). Relationship between aphid infestation and chlorophyll content in fabaceae species. Acta Biological Cracoviensia, 52(2): 76-80.

Haile, F.J., L.G. Higley, X. Ni and S.S. Quisenberry (1999). Physiological and growth tolerance in wheat to Russian wheat aphid (Homoptera: Aphididae) injury. Environmental Entomology, 28: 787-794.

Hassan, A.S. (1998). Studies on some scale insects and mealybugs infesting certain horticulture crops in newly reclaimed areas. Ph. D. Thesis, Fac. of Agric., Zagazig Univ., Egypt.

Lawson, T., J. Craigon, A.M. Tulloch, C.R. Black, J.J. Colls and G. Landon (2001). Photosynthetic responses to elevated $\mathrm{CO} 2$ and ozone in field-grown potato (Solanum tuberosum). Journal of Plant Physiology, 158: 309-323.

Little, T. M. and F. J. Hills (1972). Statistical methods in agricultural research. Berkeley, CA: University of California Public Services Offices.

Moran, R. (1982). Formulae for determination of chloropyllous pigments extracted with N,NDimethylformamide. Plant Physiol., 69: 1376- 1381.

Nabil, H. A. (2013). Relationship between Kilifia acuminata (Signoret) and chlorophyll percentage loss on mango leaves. Journal of Entomology, 10 (2):110-114.

Nabil, H.A. and Samah N. El-Shafiey (2011). Economic threshold and economic injury levels for Aulacaspis tubercularis (Newstead) on mango leaves depended on determination of chlorophyll percentage loss. Bull. Ent. Soc. Egypt, 88 : $71-78$.

Ni, X., S.S. Quisenberry, J. Markwell, T. Heng-Moss, L. Higley, F. Baxendale, G. Sarath and R. Klucas (2001). In vitro enzymatic chlorophyll catabolism in wheat elicited by cereal aphid feeding. Entomologia Experimentalis et Applicata, 101: 159-166.

Ni, X., S.S. Quisenberry, T. Heng-Moss, J. Markwell, L. Higley, F. Baxendale, G. Sarath and R. Klucas (2002). Dynamic change in photosynthetic pigments and chlorophyll degradation elicited by cereal aphid feeding. Entomologia Experimentalis et Applicata, 105: 4353.

Salem, S.A. and F.N. Zaki (1985). Economic threshold level of the citrus wax scale, Ceroplastes floridensis Comstock on citrus in Egypt. Bull. Soc. Ent. Egypt, 65: 333 - 343.

Samdur, M.Y., A.L. Singh, R.K. Mathur, P. Manivel, B.M. Chikani, H.K. Gor and M.A. Khan (2000). Field evaluation of chlorophyll meter for screening groundnut (Arachis hypogaea L.) genotypes tolerant to iron-deficiency chlorosis. Current Science Bangalore, 79: 211-214. 
النسبة المئوية للفقد فى الكلوروفيل كمؤشر لحساب الحد الاقتصادى الحرج وحد الضرر الاقتصادى لحشرة Parlatoria ziziphi (Lucas) التى تصيب أورلق البرتقال أبوسرة

\author{
حسن احمد نبيل
}

معهة بحوث وقاية النباتات - مركز البحوث الززاعية

أُجريت هذه الاراسة بقسم بحوث الحشرات القشرية والبق الدقيقى بمعهل بحوث وقاية النباتات فرع الثرقية بمركز

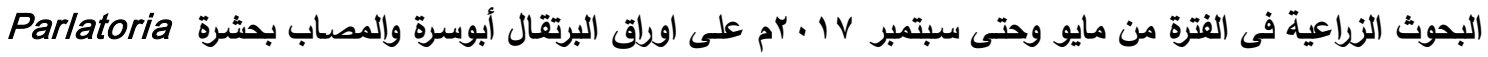
ziziphi (Lucas) الكلوروفيل.

حيث تم عمل علاقة ارتباط وانحار بين اعداد الحثرة والنسبة المئوية للفقد فى الكلوروفيل فى وحدات (بوصة مربعة إعبعة)

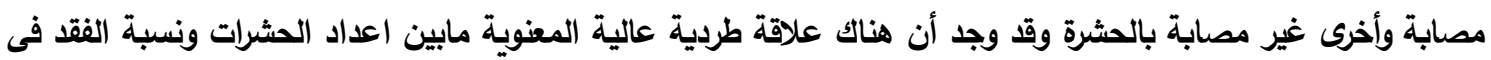
الكلوروفيل.

ومن خلال استخدام مربع كاى تم حساب الحد الاقتصادى الحرج وحد الضرر الاقتصادى وسجلا و ، ؛ ؛ حشرة| بوصة مربعة على الترتيب.

أسماء السادة المحكمين

معهز بحوث وقاية النباتات

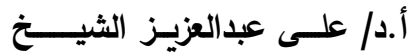
أ. أد/ محمــ الأمين محمد سويلم كلية الزراعة - جامعة المنوفية 
Menoufia J. Plant Prot., Vol. 4 June (2019): 93 - 98 